\title{
HAEMATOLOGICAL INDICES IN TRYPANOSOMA BRUCEI BRUCEI (FEDERE ISOLATE) INFECTED NIGERIAN DONKEYS (EQUUS ASINUS) TREATED WITH HOMIDIUM AND ISOMETAMIDIUM CHLORIDE
}

\author{
Queen Nneka Oparah ${ }^{1}$, Anthony Bedu kojo Sackey ${ }^{1}$, Idris Alao Lawal ${ }^{2}$, \\ Usman Shehu Abdullahi ${ }^{1}$ \\ ${ }^{1}$ Department of Veterinary Medicine, Faculty of Veterinary Medicine, \\ Ahmadu Bello University Zaria, Kaduna State, Nigeria \\ ${ }^{2}$ Department of Veterinary Parasitology and Entomology, Faculty of Veterinary Medicine, \\ Ahmadu Bello University Zaria, Kaduna State, Nigeria
}

Received 18 April 2016; Received in revised form 12 January 2017; Accepted 2 February 2017

\begin{abstract}
The efficacy of intramuscular administration of Homidium chloride (Novidium $®$ ) and Isometamidium chloride (Sécuridium ${ }^{\circledR}$ ) in Nigerian donkeys (Equus asinus) experimentally infected with T. b. brucei (Federe isolate) was investigated. Changes in haematological and serum biochemical indices were evaluated using clinical haematology and biochemistry methods. Red blood cell (RBC) count for the negative control group was significantly higher than for the positive control, Novidium ${ }^{\circledR}$ and Sécuridium ${ }^{\circledR}$-treatment groups. Haemoglobin $(\mathrm{Hb})$ concentration significantly reduced in the infected untreated group compared with other groups. Packed cell volume (PCV) was significantly different between negative and positive controls, and also between the infected untreated and treatment groups. There was significant reduction in platelet counts post-infection and post-treatment. Mean corpuscular volume (MCV) increased significantly in the treatment groups while mean corpuscular haemoglobin concentration (MCHC) significantly reduced only in the Sécuridium ${ }^{\circledR}$-treatment group. Lymphocyte count for infected untreated was non-significantly higher than for the uninfected controls, but treatment with both trypanocides recorded further increases, which were higher compared with that of the uninfected group. Post infection and treatment, aspartate aminotransferase (AST) levels increased significantly. There were non-significant differences in electrolyte ion concentrations across the groups except for chloride ion which recorded a significant reduction in the Novidium ${ }^{\circledR}$-treatment group. This experiment revealed that Nigerian donkeys infected with T. brucei brucei (Federe isolate) developed symptoms of trypanosomosis; anaemia, lymphocytosis and thrombocytopenia. Treatment with the trypanocides ameliorated effects of the infection, and results suggest that immunosuppression may not be a substantial clinical manifestation of T. brucei brucei (Federe isolate) trypanosomosis in Nigerian donkeys.
\end{abstract}

Key words: haematology, Trypanosoma brucei brucei (Federe isolate), donkey, homidium chloride, isometamidium chloride

\section{INTRODUCTION}

Donkeys constitute $70 \%$ of the African equine population, and are predominantly found in the arid and semi-arid areas providing a reliable, environmentally friendly and renewable source of draught power to millions of poor communities' worldwide (1). Primarily, Trypanosoma evansi and

Corresponding author: Dr. Queen Nneka Oparah, $\mathrm{PhD}$

E-mail address: oparah.queen@gmail.com

Present address: Department of Veterinary Medicine, Faculty of Veterinary

Medicine, Ahmadu Bello University, Zaria Kaduna State, Nigeria

Phone: +234 8026467343

Copyright: (C) 2017 Queen N.O. This is an open-access article published under the terms of the Creative Commons Attribution License which

permits unrestricted use, distribution, and reproduction in any medium,

provided the original author and source are credited.

Competing Interests: The authors have declared that no competing

interests exist.

Available Online First: 11 February 2017

Published on: 15 March 2017

http://dx.doi.org/10.1515/macvetrev-2017-0014
T. equiperdum are trypanosomes which have the equines (horses and donkeys) as their natural host. However, several reports have revealed that other trypanosome species infect donkeys in natural conditions and these species include; Trypanosoma vivax, T. brucei brucei and T. congolense $(2,3)$.

The study of health changes in animals infected with trypanosomes is very important for a better understanding of the disease epidemiology which in turn is a prerequisite for the rational design of effective control programmes against the disease (4). Information furnished by haematological and sero-biochemical analyses indicate status of the hematopoietic system and immunological responses in haemoparasitic infections, thus serving as an aid in disease diagnosis and monitoring (5).

Trypanosomosis in donkeys has not been extensively studied despite that these animals play 
an important role in the socio-economic life of the rural farming population (6), and are susceptible to this endemic disease affecting livestock (3). Therefore, this study aimed to assess the effect of experimentally induced T. brucei brucei (Federe isolate) infection in Nigerian donkeys (Equus asinus) and compare the efficacy of two veterinary trypanocides, Homidium chloride (Novidium $($ ) and Isometamidium chloride (Sécuridium ${ }^{\circledR}$ ) to ameliorate haematological and biochemical alterations due to the infection.

\section{MATERIAL AND METHODS}

\section{Experimental animals}

Twenty-four (24) apparently healthy young Nigerian donkeys (Equus asinus) of both sexes, and aged between $8-10$ months were obtained from a livestock market in Maigatari-Jigawa state, Nigeria. Young donkeys were used because they were observed to have little or no history of exposure to trypanosoma infections or resistance to trypanocides (personal communication). Upon purchase, they were transported in an open truck by road to the Faculty of Veterinary Medicine Ahmadu Bello University, Zaria-Kaduna, Nigeria. In view of previous reports on endemicity of haemoparasites, endoparasites and ectoparasites, the donkeys were screened for these infections using standard laboratory techniques (7, 8, 9). Subsequently, they were sprayed with Deltamethrin $1 \%$ pour-on (Tagros ${ }^{\circledR}$ Chemicals India Limited) against ectoparasites, routinely dewormed with febendazole (Panacur ${ }^{\circledR}$, Intervet United Kingdom Limited) at $7.5 \mathrm{mg} / \mathrm{kg}$ body weight to eliminate gastrointestinal parasites, acclimatized and kept in fly-proof pens with access to clean water, grass and whole grain feed ad libitum for the duration of the experiment which lasted 3 months (90 days).

\section{Biological material}

Trypanosoma brucei brucei (Federe isolate) used for the experiment was obtained as stabilates from the Nigerian Institute for Trypanosomiasis Research (N.I.T.R.), Kaduna, Nigeria. Two_Wistar rats were inoculated intraperitoneally with the T. brucei brucei (Federe isolate), and transported in a cage to the fly-proof laboratory animal house of the Department of Veterinary Parasitology and Entomology, Ahmadu Bello University ZariaKaduna, Nigeria. They were monitored daily for parasitaemia by Haematocrit Centrifugation
Technique (HCT) and wet mount using blood collected from the tail vein $(9,10)$. At the peak of parasitaemia ( $\geq 40$ parasites seen per field on wet mount preparation) attained 5 days post inoculation, the rats were anaesthesized using chloroform fumes and with $10 \mathrm{ml}$ syringes were bled from the heart, then pooled into a $20 \mathrm{ml}$ glass beaker containing ethylenediaminetetraacetic acid (EDTA) at $1.5 \mathrm{mg}$ / $\mathrm{ml}$ of blood as anticoagulant. The harvested blood was used to expand the parasites by multiplication into 6 other rats for subsequent inoculation of donkeys used for the study.

\section{Administered drugs}

The drugs for the experiment (Homidium chloride - Novidium ${ }^{\circledR}$ Merial, France; Isometamidium chloride - Sécuridium $\AA$, Laprovet, France) were obtained from a reliable Veterinary Pharmaceutical store in Kaduna, Nigeria. They were dissolved and reconstituted in sterile water according to manufacturer's instructions, and administered to the animals by deep intramuscular injection (I.M.) at the following dosage; $1.0 \mathrm{mg} /$ $\mathrm{kg}$ body weight (b.w.) and $0.5 \mathrm{mg} / \mathrm{kg}$ b.w. for Homidium chloride and Isometamidium chloride respectively (11).

\section{Groups of experimental animals}

The 24 donkeys (12 males and 12 females) were tagged and assigned at random into four (4) groups of six (6) animals, with both sexes equally represented as follows:

i. Group 1 (Negative Control): Uninfected donkeys.

ii. Group 2 (Positive Control): Each donkey in this group was infected with $2 \mathrm{ml}$ of blood containing $1 \times 10^{6}$ Try $/ \mathrm{ml}$ approximately and not treated.

iii. Group 3 (Novidium ${ }^{\circledR}$-treatment group): Each donkey in this group was infected with $2 \mathrm{ml}$ of blood containing $1 \times 10^{6} \mathrm{Try} / \mathrm{ml}$ approximately and treated with Novidium ${ }^{\circledR}$ at $1 \mathrm{mg} / \mathrm{kg}$ b. w.

iv. Group 4 (Sécuridium $®$-treatment group): Each donkey in this group was infected with $2 \mathrm{ml}$ of blood containing $1 \times 10^{6} \mathrm{Try} / \mathrm{ml}$ approximately and treated with Sécuridium $\AA$ at $0.5 \mathrm{mg} / \mathrm{kg}$ b. w.

Following intraperitoneal inoculation of the 6 rats (each receiving $1 \times 10^{2}$ trypanosomes in $0.2 \mathrm{ml}$ of blood) for multiplication of the trypanosome, parasitaemia was monitored daily using blood from tail vein. At peak parasitaemia ( $\geq 40$ parasites seen 
per field on wet mount) the rats were anaesthesized with chloroform and blood harvested via cardiac puncture using disposable plastic $10 \mathrm{ml}$ syringes. The harvested T. b. brucei (Federe isolate) infected blood was then pooled into a $50 \mathrm{ml}$ beaker and serially diluted using phosphate buffer saline $(\mathrm{pH}$ 7.8) to obtain a standard inoculum with a concentration of $1 \times 10^{6}$ Try $/ \mathrm{ml}$. Parasite count was estimated using a modified form of the rapid "matching" method of Herbert and Lumsden (10). This method which involves matching the microscopic appearance of a wet film of infected blood with a series of eight pictures of microscope fields representing pre-determined concentrations of trypanosomes, was modified by increasing the number of fields examined to thirty instead of the twenty described, when parasite count was extremely low $(<1$ trypanosome/20 microscope fields).

Each of the donkeys in groups 2, 3 and 4 were inoculated via the jugular vein, with $2 \mathrm{ml}$ of the inoculum. Daily monitoring of parasitaemia in the donkeys commenced 48 hours post infection using blood from the jugular vein, and employing the techniques of Woo, and Herbert and Lumsden $(9,10)$.

The trypanocidal drugs were administered to the donkeys at the second wave of peak parasitaemia ( $\geq 40$ parasites per microscope field) on day 12 post infection.

\section{Haematological and biochemical studies}

Following infection of the donkeys, blood was sampled daily and examined for the presence of T. b. brucei using the wet mount technique until parasites were detected in all the infected donkeys. Thereafter, sampling was done at three days interval with $5 \mathrm{ml}$ of blood collected from each of the infected donkeys for analysis: $2 \mathrm{ml}$ of this blood was placed in EDTA-coated vacutainer tubes for haematology, and $3 \mathrm{ml}$ placed in plain centrifuge tubes, allowed to clot, centrifuged for serum separation at $3000 \times g$ for $5 \mathrm{~min}$, and the serum harvested for biochemical analysis. Blood in EDTA tubes was used for determination of packed cell volume (PCV) by microhaematocrit centrifugation technique using the Hawksley® microhaematocrit centrifuge and reader, and the haemoglobin concentration $(\mathrm{Hb})$ was determined by cyanmethemoglobin method (8). Red blood cell (RBC) and white blood cell (WBC) counts were done using Coulter Counter (ZF6, Shimadzu, Kyoto, Japan), and differential white cell count by Haemo-Scan differential cell counter. Mean corpuscular volume (MCV), mean corpuscular haemoglobin $(\mathrm{MCH})$ and mean corpuscular haemoglobin concentration (MCHC) were calculated according to formulae of Jain (12). Total plasma protein was determined using a refractometer (Coulter Electronics Limited, Luton Bedfordshire, United Kingdom) as described by Kerr (13). Measurement of serum enzymes, metabolites and electrolytes were done using standard commercial kits and an automated clinical chemistry analyser machine (Vital Scientific Selectra XL, Spankeren Netherlands) according to established techniques (8).

\section{Data analysis}

Group data obtained for each parameter was expressed as means. Variation among mean values was subjected to analysis of variance (ANOVA). Post-hoc test analysis was done using the Tukey's multiple comparison tests. Values of $p<0.05$ were considered as statistically significant.

\section{RESULTS}

Trypanosoma brucei brucei (Federe isolate) experimental infection in twenty-four (24) Nigerian donkeys (Equus asinus) was observed to have a pre-patent period of 2-3 days post infection (p.i). Parasites were first detected in some of the infected donkeys at day 2 p.i and by day 3 p.i all the infected donkeys manifested parasitaemia. The parasitaemia was characterized by intermittent waves of peak ( $\geq 40$ parasites per microscope field) and low ( $\leq 10$ parasites per microscope field) levels, persistent until the end of the experiment for the infected untreated group (Fig. 1).

For the treatment groups (Groups 3 and 4), parasites were eliminated from peripheral circulation 24 hours post-administration of Novidium $\AA$ and Sécuridium $\AA$ respectively. Postinfection, observations in the positive control group (infected untreated) revealed significant $(p<0.05)$ reductions in values of $\mathrm{RBC}, \mathrm{Hb}, \mathrm{PCV}$ (indicating an anaemic condition), and platelets compared with the negative control (uninfected) group (Tables 1 and 2). Following treatment, the Novidium $\AA$-treatment group had RBC and platelet counts non-significantly lower than counts for the infected untreated group and the Sécuridium $®$-treatment group (Tables 1 and 2). $\mathrm{Hb}$ and $\mathrm{PCV}$ values increased significantly post treatment using both drugs, with Sécuridium ${ }^{\circledR}$ producing a higher increase than Novidium ${ }^{\circledR}$ (Table 1). $\mathrm{MCV}, \mathrm{MCH}$ and $\mathrm{MCHC}$ values for the infected untreated (Group 2) donkeys were non-significantly lower than values for the uninfected control donkeys (Table 1). Treatment with the trypanocides caused 


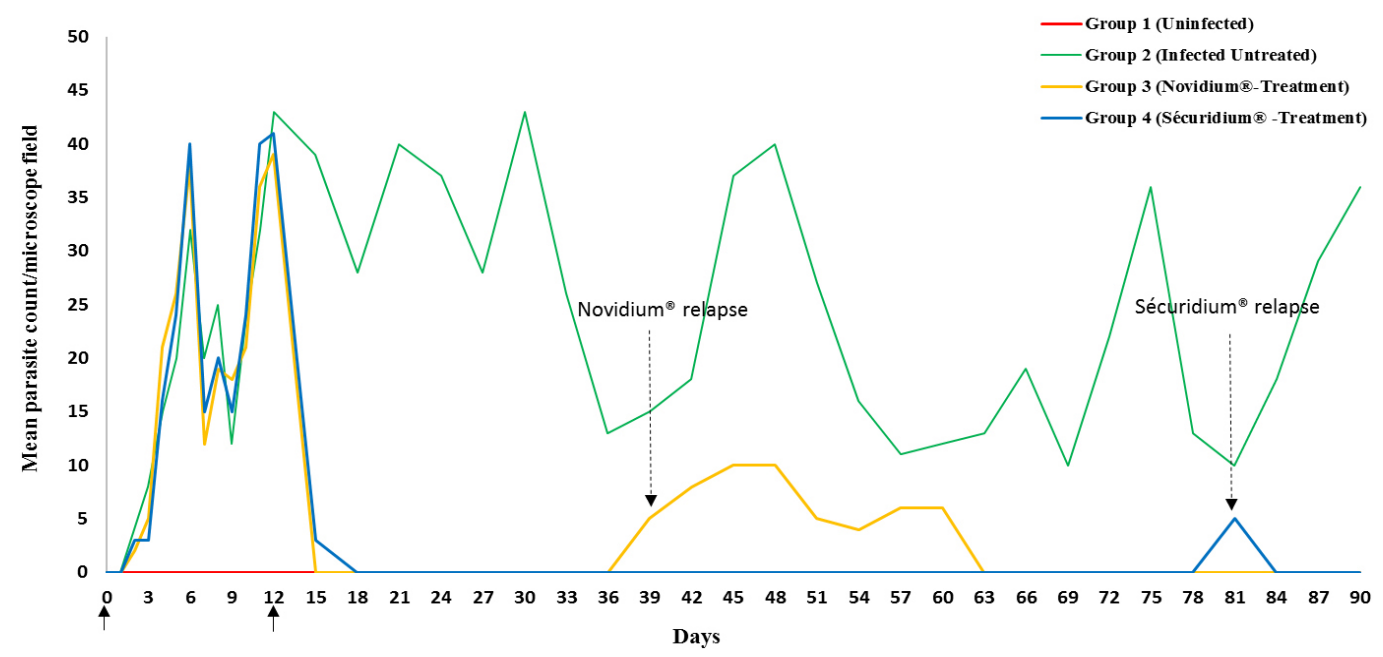

Figure 1. Parasitaemia profile of donkeys experimentally infected with Trypanosoma brucei brucei (Federe isolate) and treated with Homidium chloride $\left(\right.$ Novidium $\left.{ }^{\circledR}\right)$ and Isometamidium chloride (Sécuridium $\left.{ }^{\circledR}\right)$ at day 12 post infection.

KEY:

Day $0=$ Infection of donkeys

Day $12=$ Treatment of Groups 3 and 4 donkeys

Day 39 = Relapse detected in Group 3 donkeys (day 27 post treatment)

Day $81=$ Relapse detected in Group 4 donkeys (day 69 post treatment)

an increase in $\mathrm{MCV}$ values which were significantly $(p<0.05)$ higher than values for the infected untreated and uninfected control groups. The $\mathrm{MCH}$ only increased significantly in Novidium ${ }^{\circledR}$-treatment group while $\mathrm{MCHC}$ only reduced significantly in Sécuridium ${ }^{\circledR}$-treatment group (Table 1). Platelet counts in both treatment groups (Groups 3 and 4) were significantly $(p<0.05)$ lower than in the uninfected group, while no significant difference was recorded between the treatment groups and the infected untreated group (Table 2). Lymphocyte count recorded a non-significant increase in the infected untreated donkeys compared with the uninfected controls (Table 2). However, treatment with the trypanocides caused a further increase in the lymphocyte count which was significantly higher compared with the uninfected donkeys. The Novidium ${ }^{\circledR}$-treatment group had lymphocyte counts significantly $(p<0.005)$ higher than that of the infected untreated and uninfected controls, and nonsignificantly higher than that of the Sécuridium ${ }^{\circledR}$ treatment group (Table 2). Neutrophil count increased post infection (Group 2), however this was statistically non-significant when compared with the other groups (Table 2). Non-significant difference was recorded for total WBC and monocytes counts across all the groups (Table 2), however WBC count for the Novidium ${ }^{\circledR}$-treatment group was lowest.

Table 1. Changes in red blood cell indices of Nigerian donkeys experimentally infected with T. brucei brucei (Federe isolate) and treated with Novidium ${ }^{\circledR}$ and Sécuridium ${ }^{\circledR}$

\begin{tabular}{|c|c|c|c|c|c|c|c|}
\hline Groups & $\mathrm{N}$ & $\mathrm{RBC}\left(\times 10^{6} / \mu \mathrm{l}\right)$ & $\mathrm{Hb}(\mathrm{g} / \mathrm{dL})$ & $\operatorname{PCV}(\%)$ & $\mathrm{MCV}(\mathrm{fl})$ & $\mathrm{MCH}(\mathrm{pg})$ & $\mathrm{MCHC}(\mathrm{g} / \mathrm{dL})$ \\
\hline 1-Control Uninfected & 6 & $6.23 \pm 0.22^{\mathrm{a}}$ & $9.38 \pm 0.21^{\mathrm{a}}$ & $31.17 \pm 0.87^{\mathrm{a}}$ & $59.32 \pm 1.16^{\mathrm{a}}$ & $19.03 \pm 0.32^{\mathrm{a}}$ & $33.52 \pm 0.55^{\mathrm{a}}$ \\
\hline 2-Control Infected & 6 & $4.40 \pm 0.24^{b}$ & $7.48 \pm 0.41^{\mathrm{b}}$ & $22.50 \pm 1.18^{\mathrm{b}}$ & $54.48 \pm 0.48^{\mathrm{a}}$ & $18.12 \pm 0.30^{\mathrm{a}}$ & $32.25 \pm 0.96^{\mathrm{a}}$ \\
\hline 3-Infected Novidium ${ }^{\circledR}$ Treated & 6 & $4.17 \pm 0.40^{\mathrm{b}}$ & $8.42 \pm 0.46^{\mathrm{a}}$ & $27.67 \pm 1.50^{\mathrm{a}}$ & $64.73 \pm 1.62^{\mathrm{b}}$ & $20.60 \pm 0.19^{b}$ & $31.97 \pm 0.87^{\mathrm{a}}$ \\
\hline 4-Infected Sécuridium ${ }^{\circledR}$ Treated & 6 & $4.97 \pm 0.11^{\mathrm{b}}$ & $9.32 \pm 0.10^{\mathrm{a}}$ & $29.33 \pm 0.88^{\mathrm{a}}$ & $65.67 \pm 1.85^{\mathrm{b}}$ & $19.54 \pm 0.25^{\mathrm{a}}$ & $30.32 \pm 0.44^{\mathrm{b}}$ \\
\hline
\end{tabular}

KEY: Red Blood Cells (RBC), Haemoglobin concentration (Hb), Packed Cell Volume (PCV), Mean Corpuscular Volume (MCV), Mean Corpuscular Haemoglobin (MCH), Mean Corpuscular Haemoglobin Concentration (MCHC). N= Number of animals in each group. Means with different letters in same column for each group are statistically different at $\mathrm{p}<0.05$. Values are Mean \pm Standard Error of Mean (SEM) 
Table 2. Changes in leucocytes and platelets of Nigerian donkeys experimentally infected with T. brucei brucei (Federe isolate) and treated with Novidium ${ }^{\circledR}$ and Sécuridium ${ }^{\circledR}$

\begin{tabular}{|c|c|c|c|c|c|c|}
\hline Groups & $\mathrm{N}$ & $\mathrm{WBC}\left(\times 10^{9} / \mu \mathrm{l}\right)$ & Platelets $\left(\times 10^{9} / \mu \mathrm{l}\right)$ & Neut $(\%)$ & Lymph (\%) & Mono (\%) \\
\hline 1-Control Uninfected & 6 & $7.63 \pm 0.49^{\mathrm{a}}$ & $250.30 \pm 24.85^{\mathrm{a}}$ & $32.50 \pm 6.71^{\mathrm{a}}$ & $43.67 \pm 3.32^{\mathrm{a}}$ & $2.00 \pm 1.12^{\mathrm{a}}$ \\
\hline 2-Control Infected & 6 & $7.43 \pm 0.76^{\mathrm{a}}$ & $123.50 \pm 19.53^{b}$ & $40.17 \pm 3.70^{\mathrm{a}}$ & $50.00 \pm 2.46^{\mathrm{ab}}$ & $2.50 \pm 0.96^{\mathrm{a}}$ \\
\hline 3-Infected Novidium ${ }^{\circledR}$ Treated & 6 & $5.98 \pm 0.73^{\mathrm{a}}$ & $108.80 \pm 7.57^{\mathrm{b}}$ & $36.00 \pm 3.45^{\mathrm{a}}$ & $67.83 \pm 5.85^{\mathrm{c}}$ & $1.88 \pm 0.97^{\mathrm{a}}$ \\
\hline 4-Infected Sécuridium ${ }^{\circledR}$ Treated & 6 & $8.50 \pm 1.19^{\mathrm{a}}$ & $154.80 \pm 22.18^{\mathrm{b}}$ & $36.17 \pm 4.89^{\mathrm{a}}$ & $62.17 \pm 5.26^{\mathrm{bc}}$ & $3.13 \pm 0.69^{\mathrm{a}}$ \\
\hline
\end{tabular}

KEY: White Blood Cells (WBC), Neutrophils (Neut), Lymphocytes (Lymph), Monocytes (Mono). N= Number of animals in each group. Means with different letters in same column for each group are statistically different at $\mathrm{p}<0.05$. Values are Mean \pm Standard Error of Mean (SEM)

Total protein, albumin, creatinine and urea concentrations were non-significantly altered across the groups (Table 3). Serum enzyme levels for AST recorded a significant $(\mathrm{p}<0.05)$ increase post infection, and in the treatment groups (Groups 3 and 4), AST levels were lower but nonsignificantly different from that of the infected untreated group (Table 3). ALT and ALP levels were non-significantly altered across the groups (Table 3). Chloride ion concentration for the Novidium ${ }^{\circledR}$ treatment group was significantly $(\mathrm{p}<0.05)$ lower than for the positive and negative control groups (Table 4), while the Sécuridium ${ }^{\circledR-t r e a t m e n t ~ g r o u p ~}$ had chloride ion concentration non-significantly different from all other groups. Other electrolytes (calcium, phosphorus, sodium, potassium and bicarbonate) recorded non-significant alterations across the groups.
A relapse of infection was recorded in one of the donkeys of the Novidium ${ }^{\circledR}$-treatment group (Group 3) at day 27 post treatment with mean parasite count of $\geq 5$ parasites per microscope field. The donkey was treated 27 days post relapse detection with freshly reconstituted Novidium ${ }^{\circledR}$ injection at same dose as before ( $1 \mathrm{mg} / \mathrm{kg}$ b.w.), and the parasites were eliminated 24 hours later. For the Sécuridium ${ }^{\circledR}$ treatment group, relapse detection was at day 69 post treatment also in one of the donkeys. Treatment was repeated 48 hours post relapse detection using freshly reconstituted Sécuridium ${ }^{\circledR}$ injection at same dose as before $(0.5 \mathrm{mg} / \mathrm{kg}$ b.w.), and parasites no longer detected 24 hours later (Fig. 1). By termination of the experiment at day 90 post infection, except for the previously observed and treated relapses in groups 3 and 4, no further relapses were recorded in all the 12 infected and treated donkeys.

Table 3. Changes in serum enzymes and proteins of Nigerian donkeys experimentally infected with T. brucei brucei (Federe isolate) and treated with Novidium ${ }^{\circledR}$ and Sécuridium ${ }^{\circledR}$

\begin{tabular}{|c|c|c|c|c|c|c|c|c|}
\hline Groups & $\mathrm{N}$ & $\operatorname{AST}(\mathrm{U} / \mathrm{L})$ & ALT (U/L) & ALP (U/L) & $\begin{array}{l}\text { CREAT. } \\
(\mu \mathrm{mol} / \mathrm{L})\end{array}$ & $\begin{array}{l}\text { UREA } \\
(\mathrm{mmol} / \mathrm{L})\end{array}$ & $\mathrm{TP}(\mathrm{g} / \mathrm{L})$ & $\begin{array}{l}\text { Albumin } \\
(\mathrm{g} / \mathrm{L})\end{array}$ \\
\hline 1-Control Uninfected & 6 & $20.50 \pm 2.14^{\mathrm{a}}$ & $37.83 \pm 1.56^{\mathrm{a}}$ & $49.83 \pm 6.30^{\mathrm{a}}$ & $71.67 \pm 2.43^{a}$ & $4.37 \pm 0.14^{\mathrm{a}}$ & $68.17 \pm 1.28^{\mathrm{a}}$ & $39.00 \pm 0.63^{\mathrm{a}}$ \\
\hline 2-Control Infected & 6 & $27.67 \pm 1.45^{\mathrm{b}}$ & $39.50 \pm 4.43^{\mathrm{a}}$ & $68.50 \pm 2.39^{a}$ & $66.00 \pm 1.83^{\mathrm{a}}$ & $4.37 \pm 0.13^{\mathrm{a}}$ & $70.33 \pm 1.20^{\mathrm{a}}$ & $43.17 \pm 1.76^{\mathrm{a}}$ \\
\hline $\begin{array}{l}\text { 3-Infected Novidium } ® \\
\text { Treated }\end{array}$ & 6 & $22.67 \pm 1.41^{\mathrm{b}}$ & $39.83 \pm 2.09^{\mathrm{a}}$ & $68.17 \pm 4.64^{\mathrm{a}}$ & $70.83 \pm 2.56^{\mathrm{a}}$ & $4.30 \pm 0.15^{\mathrm{a}}$ & $67.13 \pm 1.29^{\mathrm{a}}$ & $38.63 \pm 1.45^{\mathrm{a}}$ \\
\hline $\begin{array}{l}\text { 4-Infected } \\
\text { Sécuridium } ® \text { Treated }\end{array}$ & 6 & $26.17 \pm 1.40^{\mathrm{b}}$ & $37.17 \pm 1.52^{\mathrm{a}}$ & $68.17 \pm 6.57^{\mathrm{a}}$ & $67.67 \pm 1.65^{\mathrm{a}}$ & $4.14 \pm 0.22^{\mathrm{a}}$ & $69.13 \pm 0.64^{\mathrm{a}}$ & $40.63 \pm 1.10^{\mathrm{a}}$ \\
\hline
\end{tabular}

KEY: Aspartate aminotransferase (AST), Alanine aminotransferase (ALT), Alkaline phosphatase (ALP), Creatinine (CREAT.), Total Protein (TP). N= Number of animals in each group. Means with different letters in same column for each group are statistically different at $\mathrm{p}<0.05$. Values are Mean \pm Standard Error of Mean (SEM) 
Table 4. Changes in some serum electrolytes of Nigerian donkeys experimentally infected with T. brucei brucei (Federe isolate) and treated with Novidium ${ }^{\circledR}$ and Sécuridium ${ }^{\circledR}$

\begin{tabular}{lcllllll}
\hline Groups & $\mathrm{N}$ & $\begin{array}{l}\mathrm{Ca} \\
(\mathrm{mmol} / \mathrm{L})\end{array}$ & $\begin{array}{l}\mathrm{P} \\
(\mathrm{mmol} / \mathrm{L})\end{array}$ & $\mathrm{Na}(\mathrm{mmol} / \mathrm{L})$ & $\mathrm{K}(\mathrm{mmol} / \mathrm{L})$ & $\mathrm{Cl}(\mathrm{mmol} / \mathrm{L})$ & $\begin{array}{l}\text { Bicarbonate } \\
(\mathrm{mmol} / \mathrm{L})\end{array}$ \\
\hline 1-Control Uninfected & 6 & $2.42 \pm 0.02^{\mathrm{a}}$ & $1.13 \pm 0.03^{\mathrm{a}}$ & $140.00 \pm 0.58^{\mathrm{a}}$ & $4.12 \pm 0.18^{\mathrm{a}}$ & $100.83 \pm 1.20^{\mathrm{a}}$ & $2.43 \pm 0.99^{\mathrm{a}}$ \\
2-Control Infected & 6 & $2.35 \pm 0.04^{\mathrm{a}}$ & $1.12 \pm 0.08^{\mathrm{a}}$ & $138.83 \pm 1.25^{\mathrm{a}}$ & $3.90 \pm 0.23^{\mathrm{a}}$ & $99.83 \pm 1.17^{\mathrm{a}}$ & $1.60 \pm 0.65^{\mathrm{a}}$ \\
3-Infected Novidium ${ }^{\circledR}$ Treated & 6 & $2.40 \pm 0.04^{\mathrm{a}}$ & $1.17 \pm 0.06^{\mathrm{a}}$ & $135.25 \pm 1.32^{\mathrm{a}}$ & $4.24 \pm 0.21^{\mathrm{a}}$ & $95.63 \pm 1.18^{\mathrm{b}}$ & $2.66 \pm 0.94^{\mathrm{a}}$ \\
4-Infected Sécuridium ${ }^{\circledR}$ Treated & 6 & $2.34 \pm 0.03^{\mathrm{a}}$ & $1.07 \pm 0.06^{\mathrm{a}}$ & $137.75 \pm 1.49^{\mathrm{a}}$ & $4.51 \pm 0.18^{\mathrm{a}}$ & $97.75 \pm 0.70^{\mathrm{ab}}$ & $2.62 \pm 0.93^{\mathrm{a}}$ \\
\hline
\end{tabular}

KEY: Calcium (Ca), Phosphorus (P), Sodium (Na), Potassium (K), Chloride $(\mathrm{Cl})$. N= Number of animals in each group. Means with different letters in same column for each group are statistically different at $p<0.05$. Values are Mean \pm Standard Error of Mean (SEM)

\section{DISCUSSION}

African animal trypanosomosis is characterized by fluctuating parasitaemia levels in peripheral circulation, an occurrence observed in this experiment with peak parasitaemia recorded on days $6,12,21$, $30,48,75$ and 90 post infection. Similar results have been reported in other Trypanosoma sp. experimental infections in rats (14) and pigs (15). Fluctuations in parasitaemia levels in animal trypanosomosis are due to a continuous cycle of trypanosome replication and destruction (16). This is explained by an ability of the parasites to express a sequence of antigenically variant surface glycoproteins, thereby exposing the host to a sequence of variant antigen types which leads to a failure of the host's immune response to successfully control parasitaemia (16). In this experiment, the observed fluctuating parasitaemia which was similarly characterized by periods of peaks and low parasitaemia, may be ascribed to the phenomenon of antigenic variation expressed by the infecting trypanosomes $(16,17)$. Also the relative ability of the parasites to invade extravascular spaces and organs could be implicated, thus leading to an unsteady population in peripheral circulation (18). Trypanocides used in this study were effective in eliminating the parasites from circulation. With regards to the parasite counts from the time of infection and relapse post treatment, results obtained from the study showed Sécuridium ${ }^{\circledR}$ have a better therapeutic efficacy than Novidium ${ }^{\circledR}$.

It has been established that anaemia in trypanosomiasis is a constant and inevitablefinding, and essentially haemolytic in nature, its severity determined by virulence of the infecting trypanosomes and host susceptibility $(19,20)$. The donkeys in group 1 (the uninfected group) which served as control for the experiment had haematologic values that were within reported haematologic reference intervals for donkeys (21).
Post infection reduction in PCV, $\mathrm{RBC}$ count and $\mathrm{Hb}$ concentration observed in this experiment is suggestive of a destruction of erythrocytes in the peripheral circulation of the infected donkeys. It has been reported that the mechanism of development of anaemia in T. brucei infected animals includes a destruction of the red blood cells brought about by the lashing action of the trypanosome flagella (22). The destruction of red blood cells has also been correlated to the release of pyrogens following the fulminating parasitaemia observed in trypanosomosis (20). In this study, a normocytic normochromic anaemia was observed in the group of infected untreated donkeys. The significantly higher PCV and $\mathrm{Hb}$ concentration recorded post treatment in the treated donkeys (Groups 3 and 4) compared to the infected untreated donkeys is suggestive of a recovery stage of the anaemic condition caused by the $T$, brucei bruce $i$ infection (20). Thrombocytopenia observed in this study, is similar to findings in studies on T. brucei infection in rabbits (5), and domestic and wild livestock (23). Davis (23) explains that thrombocytopenia could be a result of platelets damage due to haemorrhage, vasoconstriction or tissue damage seen in trypanosomosis. Low platelet counts could also be due to other factors which include: increased splenic sequestration of platelets, bone marrow suppression resulting to a decreased production of the platelets, or an increased destruction of the platelets due to disseminated intravascular coagulation reaction, all of which have been reported in trypanosomosis (24). The reduced platelet counts following treatment in the infected and treated donkeys (Groups 3 and 4), and which was more evident in the Novidium ${ }^{\circledR}$ treatment group (Table 2), could be related to a drug-induced immune thrombocytopenia (DIIT) (25). In DIIT, certain drugs on administration induce an autoimmune response against the 
platelets causing platelet destruction through mechanisms which are poorly understood. Another explanation for the thrombocytopenia observed post treatment could be a slow return to normal of platelet counts following the massive destruction in the course of the infection (25). However, the authors wish to express the need for a further investigation to fully understand what caused the post treatment thrombocytopenia in these donkeys (26). Leucocytosis which may be due to increase in lymphocyte (lymphocytosis), neutrophil (neutrophilia), monocytes (monocytosis) or eosinophil (eosinophilia) counts, has been implicated in trypanosomosis (5). It is believed to be part of an immunological response influenced by the ever changing variable surface glycoprotein of the infecting trypanosomes (27, 28). Lymphocytosis could also result from the host's inflammatory response due to presence of the infecting organisms (27). These support our findings in this experiment whereby lymphocyte count non-significantly increased post infection in the infected untreated donkeys compared to the uninfected donkeys. Also, lymphocyte counts were significantly high in treatment groups compared to the uninfected group, with the Novidium ${ }^{\circledR}$ treatment group recording a higher increase than the Sécuridium $®$-treatment group. The post treatment increase in lymphocyte count is attributed to increased host immune action in the presence of administered trypanocidal drugs which eliminated the parasites (27). Also, a gradual restoration of damaged tissues (e.g. the bone marrow) following elimination of the parasites, and thus enhanced immunological response to quickly mop up antigens in the body system is suspected (28). The statistically non-significant difference recorded across the groups for WBC, neutrophil and monocyte counts in this study, suggests that T. brucei brucei (Federe isolate) infection may have had a mild immunosuppressive effect in the Nigerian donkeys (Equus asinus) studied. This contrasts with findings in studies on $T$. brucei infection in rats, where significant changes in total leucocyte counts were recorded post infection and treatment (29). Therefore, there is the need to investigate the type of immune response exhibited by these Nigerian donkeys following infection with $T$. brucei brucei (Federe isolate) to understand the influence of this infection on the immune system of these species. Post treatment results (Groups 3 and 4) showing increase in $\mathrm{Hb}$ concentration and PCV close to values obtained for the uninfected control group, indicate that drugs administered have the potential to improve blood components through their trypanocidal activities, and thereby aid the restoration of cellular functions to pre-infection state. Similar observations were made in a study on T. brucei brucei experimental infection in rats (30), whereby PCV, RBC and $\mathrm{Hb}$ values which decreased significantly following the infection were reversed by trypanocidal drug treatment. Increased MCV of the red blood cells (macrocytosis) following treatment in the Nigerian donkeys (Equus asinus), indicates presence of a regenerative anaemia which is usually due to increased erythropoiesis in the bone marrow with the resultant release of macrocytic (large) immature red cells into circulation (31). The significantly higher $\mathrm{MCH}$ concentration for Novidium $\AA$-treatment group and significantly lower MCHC for Sécuridium $\AA$ treatment group in comparison to the other groups (Table 1), were within normal range reported for Nigerian donkeys (16). Reason for differences in these values are not fully understood at this time, but may be linked to individual differences amongst members of the groups with regards to response to therapy. AST levels in this experiment were within reported normal range $(16,32,33)$, but significant increases post infection and treatment were recorded (Table 3), which may be due to a relatively mild hepatocellular injury or increased levels due to haemolysed RBCs. Similar observations of increased AST activity post Trypanosoma brucei infection in gilts have been reported (34). Due to a low activity of the ALT enzyme in the liver tissue of large animals, this enzyme does not serve as a useful indicator for liver diseases in these species however; increase in serum levels can be seen in muscle diseases, inflammatory conditions and hepatic diseases accompanied by altered cell membrane permeability or necrosis (35). In this experiment, ALT levels were not significantly altered in all the groups but groups 2 and 3 donkeys had higher values (Table 3) which were within reported normal range (32), and suggests absence of muscle injury. ALP levels in this experiment were within reported normal range $(16,32)$, however higher values were recorded in groups 2, 3 and 4 compared with group 1 donkeys (Table 3 ). This could be as a result of a release of endogenous corticosteroids (36). The non-significantly altered creatinine and urea levels in this experiment (Table $3)$ were within normal range $(32,33)$ and indicate none deleterious effect on the kidney and the glomerular filtration rates. No protein disorders were observed due to the non-significant alterations in TP and ALB levels (Table 3). Electrolyte 
concentrations post infection and treatment in this experiment were all within reported normal range $(32,33)$. Calcium, phosphorus and potassium levels indicate that muscle and nerve functions, and also cell membrane integrity were not compromised. There were small disproportionate changes in chloride with respect to sodium and bicarbonate ions however, these were not significant enough to be interpreted as an acid-base disturbance.

\section{CONCLUSION}

Nigerian donkeys (Equus asinus) experimentally infected with T. brucei brucei (Federe isolate) developed symptoms of trypanosomosis which included; anaemia, lymphocytosis and thrombocytopenia. Post infection changes in haematological and serum biochemical indices in the experimental donkeys were generally mild. Trypanocides used were effective in eliminating the parasites from peripheral circulation, with Sécuridium $\AA$ seemingly having a better therapeutic efficacy on the infected animals than Novidium ${ }^{\circledR}$. This experiment confirmed susceptibility of Nigeria donkeys (Equus asinus) to infection by T. brucei brucei (Federe isolate) with haematological changes which improved upon treatment. Results also suggest that immunosuppression may not be a substantial clinical manifestation of $T$. b. brucei (Federe isolate) trypanosomosis in these donkeys, probably due to their hardy nature and innate immune response.

\section{ETHICAL APPROVAL}

For these experiments ethical clearance was sought from the Ahmadu Bello University Committee on Animal Use and Care and approval granted with the number ABUCAUC/2016/006 assigned.

\section{CONFLICT OF INTEREST STATEMENT}

The authors declared that they have no potential conflict of interest with respect to the authorship and/or publication of this article.

\section{ACKNOWLEDGMENT}

The authors wish to acknowledge the contributions of Miss Grace Adeyanju, Mallams Sa'adu Mohammed and Salisu Lawal of the Ahmadu Bello University,
Veterinary Parasitology Laboratory in providing technical assistance. We are also grateful to Mallam Hassan who assisted in care of the animals and Dr. Pius Ekong who helped with statistical analysis of data obtained.

\section{REFERENCES}

1. Fielding, D., Pearson, R. A. (Eds.) (1991). Donkeys, Mules and Horses in Tropical Agricultural Development. Proceedings of a Colloquium, September, 3-6, ISBN 0-907146066, Edinburgh University, Scotland.

2. Assefa, E., Abebe, G. (2001). Drug resistance of Trypanosoma congolense in naturally infected donkeys in North Omo zone Southern Ethiopia. Vet Para. 99: 261-271. https://doi.org/10.1016/S0304-4017(01)00489-7

3. Mesele, F., Leta, S. (2010). Prevalence rate of tsetse transmitted donkey trypanosomosis in Dale Wabera District, Western Ethiopia. Global Vet. 5(3):180183.

4. Jatau, I. D., Lawal, A. I., Agbede, R. I. S., Abdurrahman, E. M. (2012). Response of albino rats to experimental infection with primary and relapsed isolates of Trypanosoma evansi. Sahel Vet Sci. 11(1):49-57.

5. Ezebuiro, O. G. C., Yohanna, J. A., Abdulya, A., Osue, H. O., Abenga, J. N., Yakasai, M. A., Attahir, A. (2012). Haematological changes following acute Trypanosoma brucei brucei infection in rabbits. Curr Res J Biol Sci. 4(4):414-416.

6. Blench, R., de Jode, A., Gherzi, E. (2004). Donkeys in Nigeria: history, distribution and productivity. Donkeys, people and development: a resource book of Animal Traction Network for Eastern and Southern Africa (ATNESA), ACP-EU Technical Centre for Agricultural and Rural Cooperation (CTA) (pp. 210-219), Wageningen, The Netherlands.

7. Ahmed, M. I., Tijjani, A. N., Mustapha, A. R. (2008). Survey for common diseases and management practices of donkeys (Equus asinus) in Borno, State Nigeria. Nig Vet J. 29(3):1-5.

8. Sirosis, M. (2014). Laboratory Procedures for Veterinary Technicians (pp. 22-54). USA: Elsevier Health Sciences, 6th Edition.

9. Woo, P. T. K. (1969). The haematocrit centrifuge for the detection of trypanosomes in blood. Can J Zoo. 47: 921-923.

https://doi.org/10.1139/z69-150

PMid:5343381 
10. Herbert, W. J., Lumsden, W. H. R. (1976). Trypanosoma brucei: a rapid "matching" method for estimating the host's parasitaemia. Expt Para. 40(3):427-431.

https://doi.org/10.1016/0014-4894(76)90110-7

11. Knottenbelt, D. C. (2006). Saunders Equine Formulary (pp. 188-189). USA: Elsevier Health Sciences.

12. Jain, N.C. (1993). Essentials of Veterinary Haematology (pp. 103-114). USA: Wiley and Sons, New Jersey.

13. Kerr, M. G. (1989). Clinical biochemistry and haematology. In: Veterinary Laboratory Medicine (pp. 1-30), United Kingdom: Blackwell Scientific Publications, Oxford.

14. Lawal, I. A., Ameya, F., Ajanusi, O. J., Jatau, I. D., Musa, B. (2007). Distribution and morphological forms of Trypanosoma brucei in tissues/organs of experimentally infected albino rats. Proceedings of 44th Nig. Vet. Med. Assoc. (NVMA) Ann. Cong. November, 15-18, (pp. 257-260), Delta State, Nigeria.

15. Adamu, S., Barde, N., Abenga, J. N., Useh, N. M., Ibrahim, N. D. G., Esievo, K. A. N. (2009). Experimental Trypanosoma brucei infectioninduced changes in the serum profiles of lipids and cholesterol and the clinical implications in pigs. $\mathrm{J}$ Cell Ani Bio. 3(2):15-20.

16. Barry, J. D., McCulloch, R. (2001). Antigenic variation in trypanosomes: enhanced phenotypic variation in a eukaryotic parasite. Adv Para. 49: 1-70. https://doi.org/10.1016/S0065-308X(01)49037-3

17. Antia, R., Nowak, M. A., Anderson, R. M. (1996). Antigenic variation and the within-host dynamics of parasites. Immunology 93(3):985-989.

https://doi.org/10.1073/pnas.93.3.985

18. Morrison, W. I., Murray, M., Sayer, P. D., Preston, J. M. (1981). The pathogenesis of experimentally induced Trypanosoma brucei infection in the dog. I: Tissue and organ damage. Am J Path. 102(2):168-181. PMid:6110340 PMCid:PMC1903681

19. Mbaya, A., Kumshe, H., Nwosu, C. O. (2012). The Mechanisms of Anaemia in Trypanosomosis: A Review. In: Silverberg. D (Ed.) Anaemia. INTECH Open Access Publisher, Croatia Europe, pp. 269282. ISBN: 978-953-51-0138-3, InTech, Available from:http://www.intechopen.com/books/anemia/ the-mechanisms-of-anaemia-in-trypanosomosis-a-review.

https://doi.org/10.5772/29530

20. Morrison,L.J.,McLellan,S.,Sweeney,L., Chan, C.N., MacLeod, A., Tait, A., Turner, C. M. R. (2010). Role for parasite genetic diversity in differential host responses to Trypanosoma brucei infection. Inf Imm. 78(3):1096-1108.

https://doi.org/10.1128/IAI.00943-09

PMid:20086091 PMCid:PMC2825911

21. Etana, K. M., Jenbere, T. S., Bojia, E., Negussie, H. (2011). Determination of reference hematological and serum-biochemical values for working donkeys of Ethiopia. Vet Res. 4(3): 90-94.

22. Igbokwe, I. O. (1994). Mechanisms of Cellular Injury in African Trypanosomiasis. Vet Bull. 64(7):611-620.

23. Davis, C. E. (1982). Thrombocytopenia: a uniform complication of African trypanosomiasis. Acta Trop. 39(2):123-133.

PMid:6126094

24. Yusuf,O.S.,Oseni,B.S.,Olayanju,A.O.,Hassan,M.A., Ademosun, A. A., Akele, R. Y. (2013). Acute and chronic effects of Trypanosoma brucei brucei experimental infection on bone marrow and peripheral blood cells in Wistar rats. Sch J Appl Med Sci. 1(6):1036-1040.

25. Curtis, B. R. (2014). Drug-induced immune thrombocytopenia: incidence, clinical features, laboratory testing, and pathogenic mechanisms. Immunohematology, 30(2): 55-65.

PMid:25247620

26. Visentin, G. P., Liu, C. Y. (2007). Drug-induced thrombocytopenia. Hem/Oncol Clinics North Am. 21(4):685-696.

https://doi.org/10.3109/9781420045093.006

27. Satué, K., Mu-oz, A., Gardón, J. C. (2014). Interpretation of the equine leukogram. J Hem Res. 1(1):27-35.

https://doi.org/10.12974/2312-5411.2014.01.01.4

28. Adeyemi, O. S., Sulaiman, F. A. (2012). Biochemical and morphological changes in Trypanosoma brucei brucei-infected rats treated with homidium chloride and diminazene aceturate. J Basic and Clinical Physio Pharm. 23(4):179-183.

https://doi.org/10.1515/jbcpp-2012-0018

PMid:23072845

29. Ekanem, J. T., Yusuf, O. K. (2007). Some liver function indices and blood parameters in T. bruceiinfected rats treated with honey. Biokemistri, 19(2): 81-86.

30. Nwoha, R. I. O., Omamegbe, J. O. (2015). Comparative haematological changes in rats experimentally infected with Trypanosoma brucei brucei and treated with imidocarb dipropionate and diminazene aceturate. Res J Vet Sci. 8: 36-41. https://doi.org/10.3923/rjvs.2015.36.41 
31. Taylor, F. G. R., Brazil, T., Hillyer, M. H. (2010). Diagnostic Techniques in Equine Medicine (pp. 146-169). USA: Elsevier Health Sciences, 2nd Edition.

32. Garba, U. M., Sackey, A. K. B., Lawal, I. A., Esievo, K. A. N. (2015). Baseline vital haematological and serum biochemical parameters of donkeys. J. Vet. Med. and Ani Health 7(3): 94-98. https://doi.org/10.5897/JVMAH2014.0353

33. Burden,F. A.,Hazell-Smith,E., Mulugeta, G.,Patrick, V., Trawford, R., Brooks Brownlie, H. W. (2016). Reference intervals for biochemical and haematological parameters in mature domestic donkeys (Equus asinus) in the UK. Eq Vet Edu. 28(3): 134-139.

https://doi.org/10.1111/eve.12512
34. Allam, L., Ogwu, D., Agbede, R. I., Sackey, A.K.B. (2011). Hematological and serum biochemical changes in gilts experimentally infected with Trypanosoma brucei. Vet Arhiv. 81(5):597609.

35. Kaneko, J. J., Harvey, J. W. and Bruss, L. M. (2008). Clinical Biochemistry of Domestic Animals (pp. 854-858). USA: Elsevier Inc. 6th Edition.

36. Hayes, W. A. (2008). Principles and Methods of Toxicology (p.1344). USA: CRC Press, New York. 5th Edition. 